\title{
Alternative renin-angiotensin system pathways in adipose tissue and their role in the pathogenesis of obesity
}

\author{
SLAMKOVA M, ZORAD S, KrSKOVA K \\ Institute of Experimental Endocrinology, Biomedical Research Centre, Slovak Academy of Sciences, Bratislava, Slovakia \\ E-mail: miroslava.slamkova@savba.sk
}

\begin{abstract}
Adipose tissue expresses all the renin-angiotensin system (RAS) components that play an important role in the adipogenesis, lipid and glucose metabolism regulation in an auto/paracrine manner. The classical RAS has been found to be over-activated during the adipose tissue enlargement, thus elevated generation of angiotensin II (Ang II) may contribute to the obesity pathogenesis. The contemporary view on the RAS has become more complex with the discovery of alternative pathways, including angiotensin-converting enzyme 2 (ACE2)/angiotensin (Ang)-(1-7)/Mas receptor, (pro)renin receptor, as well as angiotensin IV(Ang IV)/AT4 receptor. Ang-(1-7) via Mas receptor counteracts with most of the deleterious effects of the Ang II-mediated by AT1 receptor implying its beneficial role in the glucose and lipid metabolism, oxidative stress, inflammation, and insulin resistance. Pro(renin) receptor may play a role (at least partial) in the pathogenesis of the obesity by increasing the local production of Ang II in adipose tissue as well as triggering signal transduction independently of Ang II. In this review, modulation of alternative RAS pathways in adipose tissue during obesity is discussed and the involvement of Ang-(1-7), (pro)renin and AT4 receptors in the regulation of adipose tissue homeostasis and insulin resistance is summarized.
\end{abstract}

Key words: angiotensin-(1-7), Mas receptor, (pro)renin receptor, angiotensin IV, adipose tissue, obesity, insulin resistance

Over the past decade, substantial progress has been achieved regarding the adipose tissue metabolic function knowledge. The adipose tissue is now considered to be an active endocrine organ playing significant role in the regulation of the body metabolism homeostasis.

Positive energy balance leads to the adipose tissue expansion that is associated with adipocytes hyperplasia and hypertrophia and significantly affects the overall cell biology and tissue homeostasis (Kloting and Bluher 2014). Adipose tissue enlargement is accompanied by severe dysfunctions of adipocyte with impaired glucose and fatty acid metabolism. The obesity-associated pro-inflamma- tory state and oxidative stress, as response to severe hypoxia, increase the macrophage infiltration into the adipose tissue inducing further inflammation and expression of inflammatory mediators including tumor necrosis factor $\alpha(\mathrm{TNF}-\alpha)$, interleukin 6 (IL-6), and monocyte chemoattractant protein-1 (MCP-1) and may cause dysregulation of the adipokines [adiponectin, leptin, resistin, angiotensin II (Ang II)]. The increased reactive oxygen species (ROS) secretion into peripheral blood from adipose tissue is involved in the induction of insulin resistance in skeletal muscle and adipose tissue and obesity-associated vascular diseases (Wang et al. 2007; Netzer et al. 2015).

Corresponding author: Miroslava Slamkova, Institute of Experimental Endocrinology, Biomedical Research Centre, Slovak Academy of Sciences, Dubravska cesta 9, 84505 Bratislava, Slovakia; phone: +421-2-32295-257; e-mail: miroslava.slamkova@savba.sk. 
It has been shown that the rennin-angiotensin system (RAS) is complicated and not all the physiological and pathophysiological roles of the Ang II are completely understood. Many of the other angiotensin peptides have also physiological effects. In addition to the classical RAS components, several new peptides, with interesting biological activity, have recently been discovered. The important one is angiotensin (Ang)-(1-7) produced through the Ang II degradation by angiotensin-converting enzyme 2 (ACE2). It has a counter-regulatory role by opposing many actions of Ang II on $\mathrm{AT}_{1}$ receptors (Donoghue et al. 2000; Tipnis et al. 2000). Discovering the G-protein coupled Mas, as a functional receptor (MasR) for Ang-(1-7), has clearly established the ACE2/Ang-(1-7)/MasR axis as an active pathway of the RAS and opened new possibilities of RAS components interactions (Santos et al. 2003). Moreover, the Mas-related G-protein-coupled receptor (MrgD), as a second receptor for Ang-(1-7), has been identified (Tetzner et al. 2016). To the contemporary view on the RAS has also contributed with novel receptors such as pro(renin) receptor (PRR) and angiotensin type $4\left(\mathrm{AT}_{4}\right)$ receptor identified as a transmembrane insulin regulated aminopeptidase (IRAP) playing a potential role in the regulation of glucose homeostasis (Kalupahana and Moustaid-Moussa 2012).

This review is aimed to bring recent knowledge about the role of the alternative pathways of RAS in the regulation of the adipose tissue metabolism during obesity development, focusing (i) on the ACE2/ Ang-(1-7)/MasR pathway; (ii) on the (pro)renin receptor as binding site for renin or pro(renin); (iii), and on IRAP/AT ${ }_{4}$ receptor as binding site for Ang IV (Figure 1).

\section{Local RAS in adipose tissue}

The RAS belongs to one of the oldest hormone systems. Originally, it was only considered as a cardiovascular system. The classical pathway of RAS with the major biologically active hormone Ang II has been well clarified (Figure 1). The main physiological effects of Ang II mediated by $\mathrm{AT}_{1}$ receptor lead to body fluid volume increase and blood pressure (Lavoie and Sigmund 2003). It has been found that the RAS is present in not only the circulating system, but also the peripheral tissue. RAS has been detected in different organs with multiple and specific functions (Danser 1996).

The expression of all the RAS components, including new alternative pathways, has been demonstrated in human and rodent adipose tissue (Jones et al. 1997;
Karlsson et al. 1998; Engeli et al. 1999; Pinterova et al. 2000; Gembardt et al. 2005; Achard et al. 2007; Santos et al. 2010). Adipocyte-produced angiotensinogen contributes to the circulating RAS, but the effect of the obesity on the angiotensinogen production is still inconsistent. The most of the studies have shown an increased adipocyte production of angiotensinogen during chronic energy excess in rodent obesity models and obese humans, whereas others have shown no change or reduction in its production (Kalupahana and Moustaid-Moussa 2012).

\section{Classical versus alternative RAS pathways in pathogenesis of obesity}

\section{RAS and preadipocytes differentiation}

The adipogenesis is a process of preadipocytes differentiation into the mature adipocytes (Cristancho and Lazar 2011). Adipogenesis has been extensively studied in vitro with the aim to determine the participation of adipocytes in the pathogenesis of insulin resistance to reveal the appropriate therapeutic and preventive strategies for metabolic disorders (Fonseca-Alaniz et al. 2007). During the preadipocyte differentiation, the transcription of key factors including CCAAT-enhancer-binding proteins (C/EBPs), peroxisome proliferator-activated receptor gamma (PPAR- $\gamma$ ), and adipocyte determination and differentiation-dependent factor $1 /$ sterol regulatory element binding protein-1 (ADD1/SREBP-1), are activated (Armani et al. 2010) and the expression of adipocyte markers including fatty acid binding protein 4 (FABP4), insulin-regulated glucose transporter 4 (GLUT4), leptin and adiponectin increased (Rosen and MacDougald 2006; Lefterova and Lazar 2009). The studies on the models of the PPAR- $\gamma$ expression suppression or stimulation have confirmed that the PPAR- $\gamma$ is the master regulator in the adipogenesis (Farmer 2006).

Adipogenesis has been suggested to modulate the obesity and the onset of the obesity-related adverse metabolic consequences, such as metabolic syndrome. Experimental studies have revealed that RAS expressed in the adipose tissue is implicated in the regulation of the adipocyte formation and supported a role for Ang II as a negative regulator of adipogenesis (Schling and Loffler 2001; Janke et al. 2002; Sharma et al. 2002; Matsushita et al. 2006; Mogi et al. 2006; Brucher et al. 2007; Thatcher et al. 2009). Inhibitory effect of Ang II on the adipocyte formation has been supported by observations that $\mathrm{AT}_{1}$ receptor blockers 


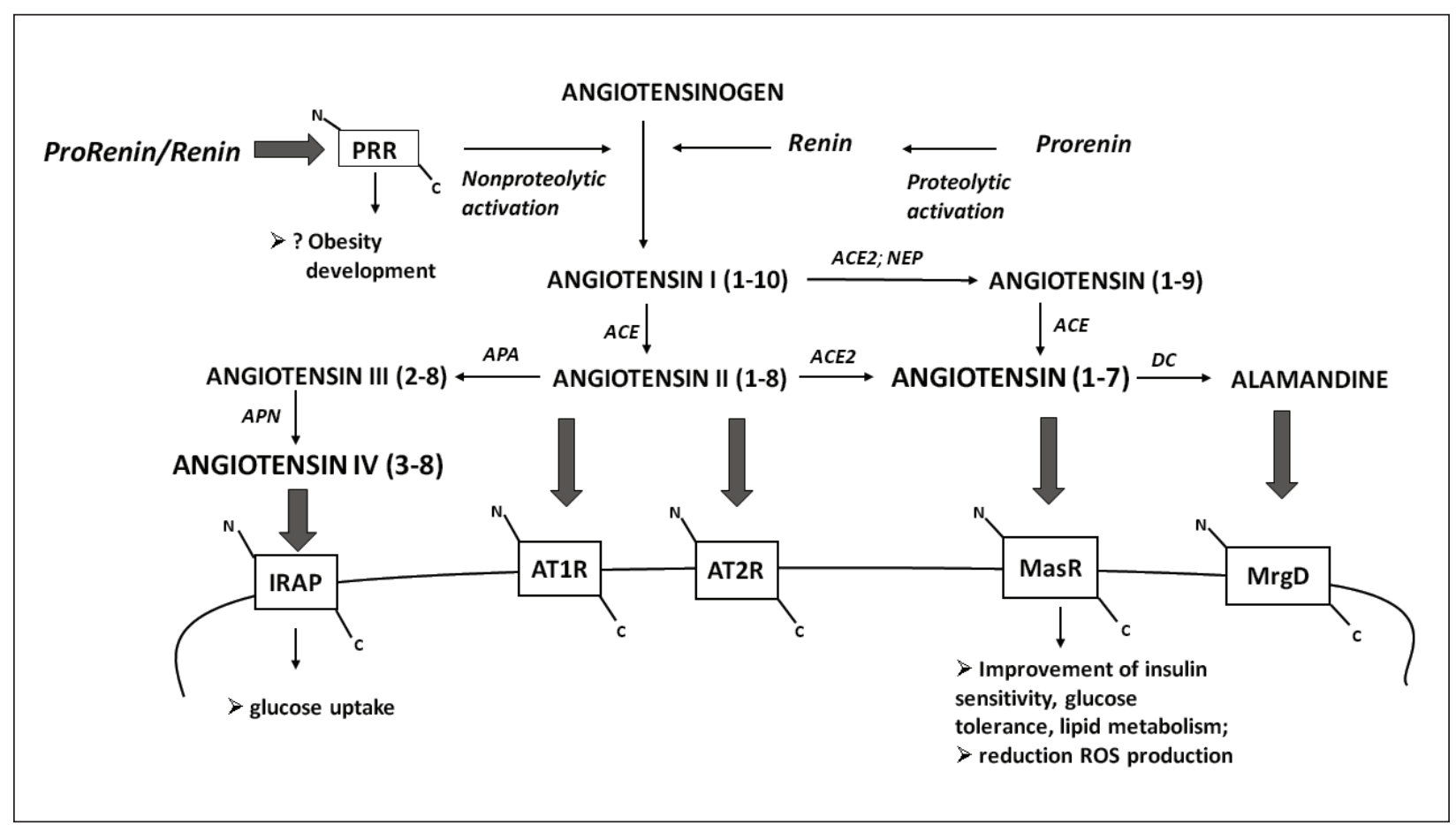

Figure 1. Schematic renin-angiotensin cascade showing the involvement of alternative components in the regulation of adipose tissue metabolism. PRR - (pro)renin receptor; ACE - angiotensin converting enzyme; ACE2 - angiotensin converting enzyme 2; NEP - neutral endopeptidase; APA - aminopeptidase A; APN - aminopeptidase N; DC - descarboxylase; IRAP - insulin regulated aminopeptidase; AT1R - angiotensin type 1 receptor; AT2R - angiotensin type 2 receptor; MasR - Mas receptor; MgprD - Mas related G-protein-coupled receptor, member D

may improve the preadipocyte differentiation (Fujimoto et al. 2004; Furuhashi et al. 2004; Zorad et al. 2006; Fuentes et al. 2010). Reduced adipocyte formation by Ang II may lead to predominance of large dysfunctional adipocytes characterized by insulinresistant state and chronic inflammation. $\mathrm{AT}_{1}$ receptor blockers restore small-differentiated adipocytes and it seems that the mechanism of their action is dependent on PPAR- $\gamma$. Small differentiated adipocytes produce less TNF- $\alpha$ and more beneficial adipokines such as adiponectin (Lenz and Fornoni 2008).

$\mathrm{AT}_{1}$ receptor and MasR are co-expressed in adipocytes and we could hypothesize considering the Ang II inhibitory effects on adipogenesis that ACE2/Ang(1-7)/MasR axis may counterbalance anti-adipogenic effect of Ang II, thus may promote preadipocyte differentiation. So far, the reports dealing with the involvement of Ang-(1-7) in adipocyte formation are almost missing. Only few studies have demonstrated that ACE2 and MasR expression steadily increase the overtime during the 3T3-L1 differentiation and have a positive regulation of Ang-(1-7)/MasR signaling to accelerate adipogenesis, particularly, in the early stage (Gupte et al. 2008; Than et al. 2013). Moreover, the authors have revealed the adipogenic effect of Ang-(1-7) through activation of MasR as well as the counteracting interplays between Ang-(1-7)/MasR and Ang II/ $\mathrm{AT}_{1} \mathrm{R}$ signaling on the adipogenesis. The mechanism by which Ang-(1-7) promoted differentiation of human and 3T3-L1 preadipocytes included the activation of phosphatidylinositol-3-kinase (PI3K) and the inhibition of PPAR- $\gamma$ phosphorylation since Ser-112 phosphorylation of this nuclear receptor inactivates its adipogenic activity (Than et al. 2013). However, more studies are needed to support the potential beneficial effects of Ang-(1-7) on the preadipocyte differentiation.

\section{RAS and metabolism of adipose tissue}

ACE/Ang II/AT $\mathbf{R}_{1}$ axis. The obesity is associated with over activation of both systemic and adipose RASs in humans and animals (Kalupahana and Moustaid-Moussa 2012). An interaction of Ang II 
with insulin signaling cascades in insulin-sensitive tissues including skeletal muscle and liver has been shown (Zhou et al. 2012), supporting a direct role for Ang II in the development of insulin resistance (Kwon and Pessin 2013; Makki et al. 2013). Although adipose tissue glucose uptake accounts for only a small part of the body, the mechanism of insulin action in this tissue is of a high importance, since the adipose RAS plays an important role in the pathogenesis of the obesity and insulin resistance (Olivares-Reyes et al. 2009). However, the molecular effect of Ang II on insulin signal transduction is controversial, since there is evidence that Ang II treatment may lead to enhanced insulin signaling through $\mathrm{AT}_{1} \mathrm{R}$ on adipocytes (Ogihara et al. 2002; Juan et al. 2005). On the other hand, Ang II can inhibit the adipose tissue insulin-signaling cascade and impair the GLUT4 translocation and glucose transport into the cells, indirectly. Several studies have demonstrated that Ang II may mediate insulin resistance by oxidative stress increase via activation of nicotinamide adenine dinucleotide phosphate (NADPH) oxidase and the ROS production as well as by stimulating the inflammatory pathways and dysregulating of the secretion of chemokines (Harrison et al. 2003; Skurk et al. 2004; Blendea et al. 2005; Lastra et al. 2009). The angiotensinogen gene silencing decreased the expression of pro-inflammatory markers, such as IL-6, TNF- $\alpha$, and MCP-1 in adipocyte cell culture (Carroll et al. 2013). In the genetically obese mice or mice with diet-induced obesity (DIO), the $\mathrm{AT}_{1}$ receptor blockade reduced the formation of the ROS in adipose tissue (Kurata et al. 2006). Ang II inhibits the secretion of adiponectin and the secretion of this anti-inflammatory hormone is increased after RAS blockers treatment (Furuhashi et al. 2004; Zorad et al. 2006).

Another mechanism underlying the effect of Ang II on insulin sensitivity is that Ang II markedly inhibits adipogenic differentiation and the blockade of the RAS prevents adipocyte hypertrophy by promoting differentiation of preadipocytes and formation of new insulin sensitive adipocytes (Sharma et al. 2002).

ACE2/Ang-(1-7)/MasR axis. The ACE2/Ang-(1-7)/ MasR axis is active in many organs, including cardiovascular system, kidneys, and adipose tissue and has been found to be implicated in vasorelaxation, antiproliferative, anti-inflammatory, and anti-fibrotic effects (Montezano et al. 2015).

The metabolic effects of Ang-(1-7) have been studied in various animal models and in vitro experiments, as summarized in Table 1. Santos and colleagues (2008) have found out that genetic deletion of
MasR in mice may have devasting effect on the lipid and glucose metabolism in adipose tissue, leading ultimately to a metabolic syndrome-like state (Santos et al. 2008). Furthermore, the data obtained on MasR knockout mice have shown that the lack of Ang-(17) action through MasR may impair the response of adipocytes to the antilipolytic effect of insulin. The authors have suggested the involvement of a decrease in the adipose PPAR- $\gamma$ expression, its target enzymes fatty acid synthase (FAS), and acetyl-CoA carboxylase (ACC) (Mario et al. 2012).

In rat model, that mimics human metabolic syndrome with insulin resistance state and dyslipidemia, generated by high-fructose diet, administration of Ang-(1-7) improved the insulin signaling in the adipose tissue through the activation of the insulin receptor/insulin receptor substrate-1/PI3K/protein kinase B (IR/IRS-1/PI3K/Akt) pathway via MasRdependent mechanism. This improvement was associated with a significant decrease in IRS-1 serine phosphorylation and activation of other proteins, including Akt substrate of $160 \mathrm{kDa}$ (AS160) and glycogen synthase kinase $3 \beta$ (GSK-3 $\beta$ ) (Giani et al. 2009; Munoz et al. 2012). Furthermore, long-term Ang-(17) treatment in rats fed with high-fructose or high-fat diets may lead to reduction of the total fat mass, adipocyte size, adipose inflammation, and superoxide production by NADPH (Marcus et al. 2013; Santos et al. 2013). In a novel transgenic rat model of inducible insulin resistance, the administration of a newly developed Ang-(1-7) nano-formulation exerts a positive effect on the insulin signaling by decreasing the serine phosphorylation of IRS-1 and increasing Akt phosphorylation in adipose tissue (Santos et al. 2014). Recent study have shown that transgenic rats with increased plasma Ang-(1-7), caused by over expression of an Ang-(1-7)-releasing fusion protein, had a significantly reduced adipose tissue mass associated with augmented action of Akt and increased expression of FABP4 and adiponectin in this tissue and decreased plasma triacylglycerides (Santos et al. 2010). Moreover, chronic high circulating Ang-(1-7) level in this transgenic rats fed with high-fat diet protect against the adipose metabolic stress decreasing proinflammatory state (Santos et al. 2012).

In vitro studies have revealed that Ang-(1-7) may protect against an oxidative stress via MasR by decreasing ROS production and increasing adiponectin production in fully differentiated 3T3-L1 adipocytes. Additionally, Ang-(1-7) has been found to improve the glucose uptake into primary cultured mice adipocytes under both, the basal and insulin-stimulated states (Liu et al. 2012). 
Table 1

The interventions in the ACE2/Ang-(1-7)/MasR axis in regard to insulin, glucose and lipid metabolism and obesity development

\begin{tabular}{|c|c|c|c|c|}
\hline \multicolumn{2}{|c|}{ Research Design } & \multicolumn{2}{|c|}{ Effects of treatmentor model } & \multirow{2}{*}{ Ref. } \\
\hline Model & Treatment & Adipose & Systemic & \\
\hline $\begin{array}{l}\text { Rats } \\
\text { High-fructose diet }\end{array}$ & $\begin{array}{l}\text { Ang-(1-7) by Alzet pumps } \\
2 \text { weeks }\end{array}$ & $\begin{array}{l}\uparrow \text { activation of insulin receptor } \\
\text { signalling pathway }\end{array}$ & $\begin{array}{c}\downarrow \text { TAG, } \downarrow \text { insulin, } \\
\downarrow \text { insulin resistant state }\end{array}$ & (Giani et al. 2009) \\
\hline $\begin{array}{l}\text { Rats } \\
\text { High-fructose diet }\end{array}$ & $\begin{array}{l}\text { Ang-(1-7) by Alzet pumps } \\
24 \text { weeks }\end{array}$ & $\begin{array}{c}\downarrow \text { fat mass, } \downarrow \text { fat cell size, } \\
\downarrow \text { NADPH activity, } \\
\downarrow \text { macrophage infiltration }\end{array}$ & $\begin{array}{l}\downarrow \text { TAG, } \downarrow \text { glucose, } \\
\uparrow \text { insulin sensitivity }\end{array}$ & (Marcus et al. 2013) \\
\hline $\begin{array}{l}\text { Rats } \\
\text { High-fructose diet }\end{array}$ & $\begin{array}{l}\text { Ang-(1-7) by Alzet pumps } \\
2 \text { weeks }\end{array}$ & $\begin{array}{c}\uparrow \text { insulin-stimulated phosphorylation } \\
\text { of Akt, AS160; } \\
\uparrow \text { insulin-stimulated phosphorylation } \\
\text { of GSK-3 } \beta\end{array}$ & $\downarrow$ insulin, $\downarrow$ TAG & (Munoz et al. 2012) \\
\hline $\begin{array}{l}\text { Rats } \\
\text { High-fat diet }\end{array}$ & $\begin{array}{l}\text { Oral administration of } \\
\text { Ang-(1-7) } \\
8 \text { weeks }\end{array}$ & $\downarrow$ abdominal fat mass & $\begin{array}{c}\downarrow \text { insulin, } \downarrow \text { glucose, } \downarrow \text { TAG, } \\
\downarrow \text { total cholesterol } \\
\uparrow \text { insulin sensitivity }\end{array}$ & (Santos et al. 2013) \\
\hline $\begin{array}{l}\text { Transgenic rats } \\
\text { (model of insulin } \\
\text { resistance) }\end{array}$ & $\begin{array}{l}\text { Oral nano-formulation of } \\
\text { Ang-(1-7) }\end{array}$ & $\begin{array}{l}\uparrow \text { activation of insulin receptor } \\
\text { signalling pathway }\end{array}$ & $\begin{array}{c}\downarrow \text { glucose, } \\
\uparrow \text { insulin sensitivity }\end{array}$ & (Santos et al. 2014) \\
\hline $\begin{array}{l}\text { Transgenic rats } \\
\text { Standard diet }\end{array}$ & $\begin{array}{l}\text { Expressing an Ang-(1-7)- } \\
\text { releasing fusion protein }\end{array}$ & $\begin{array}{c}\downarrow \text { adiposity, } \mathbf{X} \text { fat cell size, } \\
\uparrow \text { FABP4 mRNA, adiponectin mRNA, } \\
\uparrow \text { activation of insulin receptor } \\
\text { signalling pathway }\end{array}$ & $\begin{array}{l}\uparrow \text { adiponectin, } \downarrow \text { TAG, } \\
\uparrow \text { insulin sensitivity }\end{array}$ & (Santos et al. 2010) \\
\hline $\begin{array}{l}\text { Transgenic rats } \\
\text { High-fat diet }\end{array}$ & $\begin{array}{l}\text { Expressing an Ang-(1-7)- } \\
\text { releasing fusion protein }\end{array}$ & $\begin{array}{c}\downarrow \text { adiposity, } \\
\downarrow \text { COX2 mRNA, } \downarrow \text { IL-1 } \beta \text { mRNA }\end{array}$ & $\begin{array}{l}\uparrow \text { HDL cholesterol } \\
\mathbf{X} \text { insulin sensitivity }\end{array}$ & (Santos et al. 2012) \\
\hline 3T3-L1 adipocytes & $\begin{array}{l}\text { Exogenous Ang-(1-7) } \\
\text { treatment } \\
24 \mathrm{~h}\end{array}$ & $\begin{array}{c}\downarrow \text { ROS production, } \\
\uparrow \text { glucose uptake, adiponectin mRNA }\end{array}$ & & (Liu et al. 2012) \\
\hline $\begin{array}{l}\text { Human } \\
\text { subcutaneous pre- } \\
\text { adipocytes }\end{array}$ & $\begin{array}{l}\text { Gene silencing of MasR } \\
\text { Exogenous Ang-(1-7) } \\
\text { treatment }\end{array}$ & $\begin{array}{c}\uparrow \text { adypocytic differentiation } \\
\uparrow \text { FABP4, PPAR } \gamma \text { and FAS mRNA }\end{array}$ & & (Than et al. 2013) \\
\hline $\begin{array}{l}\text { ACE2 knockout } \\
\text { mice } \\
\text { High-calorie diet }\end{array}$ & $\begin{array}{l}\text { Ang-(1-7) by Alzet pumps } \\
2 \text { weeks }\end{array}$ & & $\uparrow$ insulin sensitivity & (Takeda et al. 2013) \\
\hline $\begin{array}{l}\text { Mice } \\
\text { Standard diet }\end{array}$ & $\begin{array}{l}\text { Diminazene aceturate } \\
\text { (DIZE) } \\
\text { (ACE2 activator) } 4 \text { weeks }\end{array}$ & $\begin{array}{c}\downarrow \text { adiposity } \\
\uparrow \text { ACE2 mRNA, }{ }^{-} \text {ACE mRNA } \\
\downarrow \text { FAS and ACC mRNA }\end{array}$ & $\begin{array}{l}\downarrow \text { TAG and cholesterol } \\
\mathbf{X} \text { insulin sensitivity }\end{array}$ & (de Macedo et al. 2015) \\
\hline $\begin{array}{l}\text { MasR knockout } \\
\text { mice } \\
\text { Standard diet }\end{array}$ & & $\begin{array}{c}\downarrow \text { PPAR } \gamma \text { and ACC mRNA, } \\
\downarrow \text { FAS protein }\end{array}$ & $\uparrow \mathrm{NEFA}$ & (Mario et al. 2012) \\
\hline $\begin{array}{l}\text { MasR knockout } \\
\text { mice } \\
\text { Standard diet }\end{array}$ & & $\begin{array}{l}\uparrow \text { adipose fat mass, } \\
\downarrow \text { glucose uptake, } \\
\downarrow \text { GLUT } 4 \text { protein, }\end{array}$ & $\begin{array}{c}\uparrow \text { glucose, leptin and insulin, } \\
\uparrow \text { total cholesterol and TAG, } \\
\downarrow \text { insulin sensitivity }\end{array}$ & (Santos et al. 2008) \\
\hline $\begin{array}{l}\text { Mice } \\
\text { High-fat diet }\end{array}$ & & $\begin{array}{l}\uparrow \text { ACE } 2 \text { and ADAM } 17 \text { mRNA, } \\
\mathbf{X} \text { ACE2 } 2 \text { protein and activity }\end{array}$ & $\uparrow$ ACE2 activity & (Gupte et al. 2008) \\
\hline
\end{tabular}

Abbreviation: Ang-(1-7) - angiotensin (1-7); MasR - Mas receptor; ACE - angiotensin converting enzyme; TAG - triacyglycerol; NADPH - nicotinamide adenine dinucleotide phosphate; Akt - protein kinase B; AS160 - Akt substrate of $160 \mathrm{kDa}$; GSK-3 $\beta$ - glycogen synthase kinase $3 \beta$; FABP4 - fatty acid-binding protein 4 ; COX2 - cyclooxygenase 2 ; IL-1 $\beta$ - interleukin $1 \beta$; HDL - high density lipoprotein; ROS - reactive oxygen species; PPAR $\gamma$ - peroxisome proliferator-activated receptor $\gamma$; FAS - fatty acid synthase; ACC - acetyl-CoA carboxylase; NEFA - non-esterified fatty acids; GLUT4 - glucose transporter type 4; ADAM17 - disintegrin and metalloproteinase domain-containing protein 17.

Explanatory notes: $\uparrow$ - increase, $\downarrow$ - decrease, $\mathrm{X}$ - without alteration. 
The role of the endogenous ACE2 in maintaining the insulin sensitivity and metabolic profile has been studied using ACE2 knockout mice (Takeda et al. 2013) or by the administration of ACE2 activator, diminazene aceturate (DIZE) (de Macedo et al. 2015). The results have revealed that ACE2 protects against high-calorie diet-induced insulin resistance in mice (Takeda et al. 2013). Activation of ACE2 by oral DIZE treatment in mice improved the plasma lipid profile, decreased the gene transcription of adipogenesis-related proteins (FAS, ACC), lowered the body weight, and reduced adipose tissue mass (de Macedo et al. 2015). Gupte et al. (2008) have demonstrated that ACE2 expression in adipocytes is dysregulated in high-fat diet fed mice compared with the low-fat diet fed controls.

Taken together, these results may imply a beneficial role of ACE2/Ang-(1-7)/MasR axis in the glucose and lipid metabolisms, oxidative stress, and insulin resistance as opposed to the ACE/AngII/AT R axis, which is activated in obesity-associated metabolic diseases. Moreover, these results may indicate that in addition to ACE inhibitors and AT R blockers, MasR agonists and ACE2 activators may represent new drugs for the treatment of metabolic syndrome.

Ang IV/AT 4 receptor axis. Angiotensin IV (Ang IV) has attracted a lot of attention, due to its unique role in the memory and learning enhancing and regulation of insulin signaling in the brain (Gard 2008; Wong et al. 2011). IRAP (EC 3.4.11.3.) has been identified as a placental leucin aminopeptidase/oxytocinase (Rogi et al. 1996) and also as the specific binding site for Ang IV in the brain $\mathrm{AT}_{4}$ receptor (Albiston et al. 2001). In insulin-responsive cells IRAP accompanies GLUT4 in specialized storage vesicles (GSV) cycling within intracellular compartments at the basal state (Keller et al. 1995; Ross et al. 1996). However, IRAP has been found in a range of tissues independently of GLUT4 expression (Chai et al. 2004).

IRAP is an essential regulator of the glucose uptake into the insulin-responsive cells. Adipose and muscle cells have a specialized mechanism to retain GSV intracellularly in the absence of insulin. IRAP possesses of three domains: extracellular catalytic, transmembrane, and $\mathrm{N}$-terminal cytoplasmic that interacts with three proteins - tankyrase (Chi and Lodish 2000), acyl-CoA dehydrogenase (ACD) (Katagiri et al. 2002), and formins (Tojo et al. 2003). The interaction of these proteins with IRAP appears to be involved in vesicular retention at the basal state and their trafficking to the cell surface upon insulin stimulation (Keller et al. 1995; Chai et al. 2004; Keller 2004). Thus, in response to insulin, GSV are translo- cated to plasma membrane where GLUT4 facilitates the glucose uptake into the cells and catalytic domain of IRAP gets from vesicle lumen to extracellular cell surface (Kandror et al. 1994; Bryant et al. 2002). IRAP belongs to the M1 family of $\mathrm{Zn}$-dependent metallopeptidases and it is considered as a major protein in the GSV (Jordens et al. 2010). Catalytic domain of IRAP is responsible for the extracellular breakdown of peptide substrates such oxytocin, vasopressin, lysbradykinin, and somatostatin (Yamahara et al. 2000; Chai et al. 2004; Fernando et al. 2005; Wallis et al. 2007).

IRAP, as a regulator of the glucose uptake, is suggested to play a role in the obesity pathogenesis. Insulin resistance is associated with an abnormal subcellular distribution and impaired translocation of GSV to plasma membrane. GLUT4 and IRAP are accumulated in high-density membrane fraction in basal state and insulin is not able to stimulate their trafficking (Sinha et al. 1991; Garvey et al. 1998; Maianu et al. 2001; Keller 2004). In vitro studies, using 3T3-L1 cells, have determined that cytosolic tail of IRAP is likely to be associated with AS160 at the basal state and dissociates in the response of insulin enabling the GSV to translocate to the cell surface (Larance et al. 2005; Peck et al. 2006).

The role of IRAP in the regulation of metabolism has been confirmed by the study of Niwa and co-workers (2015) who have found that the IRAPknockout mice may be protected from the development of high-fat diet-induced obesity. Glucose and insulin tolerance tests have revealed that the glucose disposal and the hypoglycemic effect of insulin are pronounced in IRAP-knockout mice after a high-fat diet (Niwa et al. 2015).

We may only hypothesize from the previous data that besides the effect of IRAP on the modulation of the glucose uptake by increasing the GLUT4 trafficking, another possible mechanism might be involved. It has been shown that endogenous IRAP substrate, oxytocin, regulates food intake, adipose tissue homeostasis and adipogenesis (Eckertova et al. 2011; Altirriba et al. 2015; Blevins and Baskin 2015) and decreased plasma oxytocin level has been found in obese mice, rats, and humans (Morton et al. 2012; Gajdosechova et al. 2014; Qian et al. 2014; Plante et al. 2015). Moreover, oxytocin or oxytocin receptor deficient mice develop obesity and impaired glucose tolerance (Takayanagi et al. 2008; Camerino 2009). We have previously shown that obesity-associated reduction in plasma oxytocin levels is due to increased peripheral peptide degradation by adipose tissue and liver, rather than changes in hormone synthesis 
(Gajdosechova et al. 2014). Thus, inhibition of oxytocinase activity of IRAP may prolong the beneficial peptide action on the adipose tissue metabolism and insulin sensitivity. The inhibitors of IRAP activity or compounds that could attract IRAP and GSV trafficking to the cell membrane in order to facilitate glucose transport may represent a therapeutic potential for the treatment of resistant obesity (Amri 2016).

The concept of Ang IV as an inhibitor of IRAP and its positive central effects on the learning and memory have stimulated the development of new selective inhibitors of IRAP (Albiston et al. 2008; Albiston et al. 2011; Mountford et al. 2014). However, the impact of IRAP/AT $R$ axis on the energy metabolism has been hardly even elucidated and there is need for further studies that will open a view into the IRAP complex physiological effects.

(Pro)renin/renin receptor (PPR) axis. The discovery of the PRR highlights the role of the cell surface in Ang II generation and opens new perspectives on the tissue RAS and prorenin or renin effects independent of Ang II (Nguyen et al. 2002). PRR is a single transmembrane domain receptor containing 350 amino acids that interacts with V-ATPase (Nguyen and Contrepas 2008). PRR specifically binds both the (pro)renin and renin. The binding of renin to PRR induces a 4 -fold increase in the catalytic efficiency of angiotensinogen conversion to Ang I, while the binding of (pro)renin leads to non-enzymatic activation of this renin precursor (Nguyen et al. 2002). Moreover, binding of (pro)renin or renin to PRR triggers Ang II-independent intracellular signaling pathways associated with the activation of the mitogen-activated protein kinases (MAPK) and extracellular signal-regulated kinases 1 and 2 (ERK1/2) cascade, and the promyelocytic zinc finger transcription factor (PLZF). Activated PLZF suppresses PRR gene expression and stimulates p85a subunit of PI3K (Schefe et al. 2006; Nguyen and Contrepas 2008). In mesangial cells, the activation of ERK1/2 pathway increased transcription of transforming growth factor $\beta 1$ (TGF- $\beta 1$ ) and expression of molecules involved in fibrosis and inflammation (Huang et al. 2007).

PRR is expressed in many tissues including brain, adipose tissue, endothelial cells, vascular smooth muscle cells, skeletal muscle, and kidney (Danser and Deinum 2005). The expression of PRR in adipose tissue has been found in both subcutaneous and visceral fat depots in humans as well as rodents (Nagai et al. 2009; Achard et al. 2011; Tan et al. 2014) and the development of obesity has been found to be accompanied by PRR upregulation in adipose tissue (Achard et al. 2007; Achard et al. 2011; Tan et al. 2014).
Accordingly, in mice fed with high-fat/high-carbohydrate diet or in fructose-fed rats, inhibition of PRR using the handle region peptide (HRP), a PRR blocker, led to a reduction of visceral fat mass and adipocyte size with simultaneous improvement of the glucose tolerance, suggesting at least a partial role for PRR in the insulin resistance development (Nagai et al. 2009; Tan et al. 2014; Tan et al. 2016). Tan and co-workers (2014) have elucidated a potential mechanisms implicated in these observations as the stimulation of the adipogenesis, angiogenesis, and adiponectin production in subcutaneous adipose tissue accompanying by reduced expression of inflammatory markers in visceral fat depots after HRP treatment leading to the activation of healthy fat storage in subcutaneous adipose tissue and normalization of the plasma free acid and triglyceride levels (Tan et al. 2014; Tan et al. 2016).

In 3T3-L1 cells, knockdown of PRR by gene silencing significantly decreased mRNA abundance of PPAR- $\gamma$ and FABP4, indicating an important role for PRR in adipogenesis and fatty acid storage in adipocytes (Wu et al. 2016). The specific deletion of PRR in adipocytes of male mice fed by a standard diet induced a marked reduction in all white adipose tissues without abnormal distribution of fat pads. Despite the lipodystrophy accompanied by hepatic steatosis, adipocyte-PRR-deficient mice had normal glucose tolerance and decreased fasting glucose level. Interestingly, high-fat-fed mice with adipocyte-PRR deficiency were resistant to diet-induced obesity and had improved glucose tolerance and fasting blood glucose when compared with wild type control (Wu et al. 2016). These data have pointed out the importance of the adipose tissue PRR role in the normal development of adipocytes, lipid, glucose, and insulin homeostasis.

These new and preliminary findings may indicate that renin and (pro)renin via PRR, by Ang II-dependent or -independent manner, may play an important role in the modulation of the adipose tissue homeostasis and functions, and that PRR may substantially contribute to the pathophysiology of obesity and insulin resistance.

\section{Perspectives and conclusion}

The research progress made over the past few decade has defined the role of the alternative RAS pathways in the regulation of the adipose tissue metabolism. In addition to cardiovascular system, the establishing the active and functional ACE2/Ang(1-7)/MasR axis, as a counter regulatory pathway of 
deleterious effects of Ang II in adipose tissue, opens a new perspective for the metabolic disorder pharmacotherapy. Demonstration of the importance of adipocyte (pro)renin receptor in the normal development of adipose tissue and its potential implication in obesity and insulin homeostasis may consider the (pro)renin receptor for a possible novel therapeutic target. Nevertheless, further investigation is neces- sary to identify the mechanisms by which the (pro) renin receptor regulates the adipose tissue and overall body metabolism.

\section{Acknowledgement}

This work was supported by VEGA 2/0174/14 and APVV-15-0229 grants.

\section{References}

Achard V, Boullu-Ciocca S, Desbriere R, Nguyen G, Grino M. Renin receptor expression in human adipose tissue. Am J Physiol Regul Integr Comp Physiol 292, R274-282, 2007.

Achard V, Tassistro V, Boullu-Ciocca S, Grino M. Expression and nutritional regulation of the (pro)renin receptor in rat visceral adipose tissue. J Endocrinol Invest 34, 840-846, 2011.

Albiston AL, McDowall SG, Matsacos D, Sim P, Clune E, Mustafa T, Lee J, Mendelsohn FA, Simpson RJ, Connolly LM, Chai SY. Evidence that the angiotensin IV (AT(4)) receptor is the enzyme insulin-regulated aminopeptidase. J Biol Chem 276, 48623-48626, 2001.

Albiston AL, Morton CJ, Ng HL, Pham V, Yeatman HR, Ye S, Fernando RN, De Bundel D, Ascher DB, Mendelsohn FA, Parker MW, Chai SY. Identification and characterization of a new cognitive enhancer based on inhibition of insulin-regulated aminopeptidase. FASEB J 22, 4209-4217, 2008.

Albiston AL, Diwakarla S, Fernando RN, Mountford SJ, Yeatman HR, Morgan B, Pham V, Holien JK, Parker MW, Thompson PE, Chai SY. Identification and development of specific inhibitors for insulin-regulated aminopeptidase as a new class of cognitive enhancers. Br J Pharmacol 164, 37-47, 2011.

Altirriba J, Pataky Z, Golay A, Rohner-Jeanrenaud F. [Oxytocin: metabolic effects and potential use for obesity treatment]. Rev Med Suisse 11, 97-100, 2015.

Amri EZ. Editorial: Oxytocin: Control of Bone and Fat Mass and Metabolism. Front Endocrinol (Lausanne) 7, 27, 2016.

Armani A, Mammi C, Marzolla V, Calanchini M, Antelmi A, Rosano GM, Fabbri A, Caprio M. Cellular models for understanding adipogenesis, adipose dysfunction, and obesity. J Cell Biochem 110, 564-572, 2010.

Blendea MC, Jacobs D, Stump CS, McFarlane SI, Ogrin C, Bahtyiar G, Stas S, Kumar P, Sha Q, Ferrario CM, Sowers JR. Abrogation of oxidative stress improves insulin sensitivity in the Ren-2 rat model of tissue angiotensin II overexpression. Am J Physiol Endocrinol Metab 288, E353-359, 2005.

Blevins JE, Baskin DG. Translational and therapeutic potential of oxytocin as an anti-obesity strategy: Insights from rodents, nonhuman primates and humans. Physiol Behav 152, 438-449, 2015.

Brucher R, Cifuentes M, Acuna MJ, Albala C, Rojas CV. Larger anti-adipogenic effect of angiotensin II on omental preadipose cells of obese humans. Obesity (Silver Spring) 15, 1643-1646, 2007.

Bryant NJ, Govers R, James DE. Regulated transport of the glucose transporter GLUT4. Nat Rev Mol Cell Biol 3, 267-277, 2002.

Camerino C. Low sympathetic tone and obese phenotype in oxytocin-deficient mice. Obesity (Silver Spring) 17, 980-984, 2009.

Carroll WX, Kalupahana NS, Booker SL, Siriwardhana N, Lemieux M, Saxton AM, Moustaid-Moussa N. Angiotensinogen gene silencing reduces markers of lipid accumulation and inflammation in cultured adipocytes. Front Endocrinol (Lausanne) 4, 10, 2013.

Cristancho AG, Lazar MA. Forming functional fat: a growing understanding of adipocyte differentiation. Nat Rev Mol Cell Biol 12, 722-734, 2011.

Danser AH. Local renin-angiotensin systems. Mol Cell Biochem 157, 211-216, 1996.

Danser AH, Deinum J. Renin, prorenin and the putative (pro)renin receptor. J Renin Angiotensin Aldosterone Syst 6, 163-165, 2005.

de Macedo SM, Guimarares TA, Andrade JM, Guimaraes AL, Batista de Paula AM, Ferreira AJ, Sousa Santos SH. Angiotensin converting enzyme 2 activator (DIZE) modulates metabolic profiles in mice, decreasing lipogenesis. Protein Pept Lett 22, 332-340, 2015. 
Donoghue M, Hsieh F, Baronas E, Godbout K, Gosselin M, Stagliano N, Donovan M, Woolf B, Robison K, Jeyaseelan R, Breitbart RE, Acton S. A novel angiotensin-converting enzyme-related carboxypeptidase (ACE2) converts angiotensin I to angiotensin 1-9. Circ Res 87, E1-9, 2000.

Eckertova M, Ondrejcakova M, Krskova K, Zorad S, Jezova D. Subchronic treatment of rats with oxytocin results in improved adipocyte differentiation and increased gene expression of factors involved in adipogenesis. Br J Pharmacol 162, 452-463, 2011.

Engeli S, Gorzelniak K, Kreutz R, Runkel N, Distler A, Sharma AM. Co-expression of renin-angiotensin system genes in human adipose tissue. J Hypertens 17, 555-560, 1999.

Farmer SR. Transcriptional control of adipocyte formation. Cell Metab 4, 263-273, 2006.

Fernando RN, Larm J, Albiston AL, Chai SY. Distribution and cellular localization of insulin-regulated aminopeptidase in the rat central nervous system. J Comp Neurol 487, 372-390, 2005.

Fonseca-Alaniz MH, Takada J, Alonso-Vale MI, Lima FB. Adipose tissue as an endocrine organ: from theory to practice. J Pediatr (Rio J) 83, S192-203, 2007.

Fuentes P, Acuna MJ, Cifuentes M, Rojas CV. The anti-adipogenic effect of angiotensin II on human preadipose cells involves ERK1,2 activation and PPARG phosphorylation. J Endocrinol 206, 75-83, 2010.

Fujimoto M, Masuzaki H, Tanaka T, Yasue S, Tomita T, Okazawa K, Fujikura J, Chusho H, Ebihara K, Hayashi T, Hosoda K, Nakao K. An angiotensin II AT1 receptor antagonist, telmisartan augments glucose uptake and GLUT4 protein expression in 3T3-L1 adipocytes. FEBS Lett 576, 492-497, 2004.

Furuhashi M, Ura N, Takizawa H, Yoshida D, Moniwa N, Murakami H, Higashiura K, Shimamoto K. Blockade of the renin-angiotensin system decreases adipocyte size with improvement in insulin sensitivity. J Hypertens 22, 1977-1982, 2004.

Gajdosechova L, Krskova K, Segarra AB, Spolcova A, Suski M, Olszanecki R, Zorad S. Hypooxytocinaemia in obese Zucker rats relates to oxytocin degradation in liver and adipose tissue. J Endocrinol 220, 333-343, 2014.

Gard PR. Cognitive-enhancing effects of angiotensin IV. BMC Neurosci 9 Suppl 2, S15, 2008.

Garvey WT, Maianu L, Zhu JH, Brechtel-Hook G, Wallace P, Baron AD. Evidence for defects in the trafficking and translocation of GLUT4 glucose transporters in skeletal muscle as a cause of human insulin resistance. J Clin Invest 101, 2377-2386, 1998.

Gembardt F, Sterner-Kock A, Imboden H, Spalteholz M, Reibitz F, Schultheiss HP, Siems WE, Walther T. Organspecific distribution of ACE2 mRNA and correlating peptidase activity in rodents. Peptides 26, 1270-1277, 2005.

Giani JF, Mayer MA, Munoz MC, Silberman EA, Hocht C, Taira CA, Gironacci MM, Turyn D, Dominici FP. Chronic infusion of angiotensin-(1-7) improves insulin resistance and hypertension induced by a high-fructose diet in rats. Am J Physiol Endocrinol Metab 296, E262-271, 2009.

Gupte M, Boustany-Kari CM, Bharadwaj K, Police S, Thatcher S, Gong MC, English VL, Cassis LA. ACE2 is expressed in mouse adipocytes and regulated by a high-fat diet. Am J Physiol Regul Integr Comp Physiol 295, R781-788, 2008.

Harrison DG, Cai H, Landmesser U, Griendling KK. Interactions of angiotensin II with NAD(P)H oxidase, oxidant stress and cardiovascular disease. J Renin Angiotensin Aldosterone Syst 4, 51-61, 2003.

Huang Y, Noble NA, Zhang J, Xu C, Border WA. Renin-stimulated TGF-beta1 expression is regulated by a mitogenactivated protein kinase in mesangial cells. Kidney Int 72, 45-52, 2007.

Chai SY, Fernando R, Peck G, Ye SY, Mendelsohn FA, Jenkins TA, Albiston AL. The angiotensin IV/AT4 receptor. Cell Mol Life Sci 61, 2728-2737, 2004.

Chi NW, Lodish HF. Tankyrase is a golgi-associated mitogen-activated protein kinase substrate that interacts with IRAP in GLUT4 vesicles. J Biol Chem 275, 38437-38444, 2000.

Janke J, Engeli S, Gorzelniak K, Luft FC, Sharma AM. Mature adipocytes inhibit in vitro differentiation of human preadipocytes via angiotensin type 1 receptors. Diabetes 51, 1699-1707, 2002.

Jones BH, Standridge MK, Moustaid N. Angiotensin II increases lipogenesis in 3T3-L1 and human adipose cells. Endocrinology 138, 1512-1519, 1997.

Jordens I, Molle D, Xiong W, Keller SR, McGraw TE. Insulin-regulated aminopeptidase is a key regulator of GLUT4 trafficking by controlling the sorting of GLUT4 from endosomes to specialized insulin-regulated vesicles. Mol Biol Cell 21, 2034-2044, 2010.

Juan CC, Chien Y, Wu LY, Yang WM, Chang CL, Lai YH, Ho PH, Kwok CF, Ho LT. Angiotensin II enhances insulin sensitivity in vitro and in vivo. Endocrinology 146, 2246-2254, 2005.

Kalupahana NS, Moustaid-Moussa N. The renin-angiotensin system: a link between obesity, inflammation and insulin resistance. Obes Rev 13, 136-149, 2012. 
Kandror KV, Yu L, Pilch PF. The major protein of GLUT4-containing vesicles, gp160, has aminopeptidase activity. J Biol Chem 269, 30777-30780, 1994.

Karlsson C, Lindell K, Ottosson M, Sjostrom L, Carlsson B, Carlsson LM. Human adipose tissue expresses angiotensinogen and enzymes required for its conversion to angiotensin II. J Clin Endocrinol Metab 83, 3925-3929, 1998.

Katagiri H, Asano T, Yamada T, Aoyama T, Fukushima Y, Kikuchi M, Kodama T, Oka Y. Acyl-coenzyme A dehydrogenases are localized on GLUT4-containing vesicles via association with insulin-regulated aminopeptidase in a manner dependent on its dileucine motif. Mol Endocrinol 16, 1049-1059, 2002.

Keller SR, Scott HM, Mastick CC, Aebersold R, Lienhard GE. Cloning and characterization of a novel insulin-regulated membrane aminopeptidase from Glut4 vesicles. J Biol Chem 270, 23612-23618, 1995.

Keller SR. Role of the insulin-regulated aminopeptidase IRAP in insulin action and diabetes. Biol Pharm Bull 27, 761-764, 2004

Kloting N, Bluher M. Adipocyte dysfunction, inflammation and metabolic syndrome. Rev Endocr Metab Disord 15, 277-287, 2014.

Kurata A, Nishizawa H, Kihara S, Maeda N, Sonoda M, Okada T, Ohashi K, Hibuse T, Fujita K, Yasui A, Hiuge A, Kumada M, Kuriyama H, Shimomura I, Funahashi T. Blockade of Angiotensin II type-1 receptor reduces oxidative stress in adipose tissue and ameliorates adipocytokine dysregulation. Kidney Int 70, 1717-1724, 2006.

Kwon H, Pessin JE. Adipokines mediate inflammation and insulin resistance. Front Endocrinol (Lausanne) 4, 71, 2013.

Larance M, Ramm G, Stockli J, van Dam EM, Winata S, Wasinger V, Simpson F, Graham M, Junutula JR, Guilhaus $\mathrm{M}$, James DE. Characterization of the role of the Rab GTPase-activating protein AS160 in insulin-regulated GLUT4 trafficking. J Biol Chem 280, 37803-37813, 2005.

Lastra G, Habibi J, Whaley-Connell AT, Manrique C, Hayden MR, Rehmer J, Patel K, Ferrario C, Sowers JR. Direct renin inhibition improves systemic insulin resistance and skeletal muscle glucose transport in a transgenic rodent model of tissue renin overexpression. Endocrinology 150, 2561-2568, 2009.

Lavoie JL, Sigmund CD. Minireview: overview of the renin-angiotensin system--an endocrine and paracrine system. Endocrinology 144, 2179-2183, 2003.

Lefterova MI, Lazar MA. New developments in adipogenesis. Trends Endocrinol Metab 20, 107-114, 2009.

Lenz O, Fornoni A. Renin-angiotensin system blockade and diabetes: moving the adipose organ from the periphery to the center. Kidney Int 74, 851-853, 2008.

Liu C, Lv XH, Li HX, Cao X, Zhang F, Wang L, Yu M, Yang JK. Angiotensin-(1-7) suppresses oxidative stress and improves glucose uptake via Mas receptor in adipocytes. Acta Diabetol 49, 291-299, 2012.

Maianu L, Keller SR, Garvey WT. Adipocytes exhibit abnormal subcellular distribution and translocation of vesicles containing glucose transporter 4 and insulin-regulated aminopeptidase in type 2 diabetes mellitus: implications regarding defects in vesicle trafficking. J Clin Endocrinol Metab 86, 5450-5456, 2001.

Makki K, Froguel P, Wolowczuk I. Adipose tissue in obesity-related inflammation and insulin resistance: cells, cytokines, and chemokines. ISRN Inflamm 2013, 139239, 2013.

Marcus Y, Shefer G, Sasson K, Kohen F, Limor R, Pappo O, Nevo N, Biton I, Bach M, Berkutzki T, Fridkin M, Benayahu D, Shechter Y, Stern N. Angiotensin 1-7 as means to prevent the metabolic syndrome: lessons from the fructose-fed rat model. Diabetes 62, 1121-1130, 2013.

Mario EG, Santos SH, Ferreira AV, Bader M, Santos RA, Botion LM. Angiotensin-(1-7) Mas-receptor deficiency decreases peroxisome proliferator-activated receptor gamma expression in adipocytes. Peptides 33, 174-177, 2012.

Matsushita K, Wu Y, Okamoto Y, Pratt RE, Dzau VJ. Local renin angiotensin expression regulates human mesenchymal stem cell differentiation to adipocytes. Hypertension 48, 1095-1102, 2006.

Mogi M, Li JM, Iwanami J, Min LJ, Tsukuda K, Iwai M, Horiuchi M. Angiotensin II type-2 receptor stimulation prevents neural damage by transcriptional activation of methyl methanesulfonate sensitive 2. Hypertension 48, 141-148, 2006.

Montezano AC, Dulak-Lis M, Tsiropoulou S, Harvey A, Briones AM, Touyz RM. Oxidative stress and human hypertension: vascular mechanisms, biomarkers, and novel therapies. Can J Cardiol 31, 631-641, 2015.

Morton GJ, Thatcher BS, Reidelberger RD, Ogimoto K, Wolden-Hanson T, Baskin DG, Schwartz MW, Blevins JE. Peripheral oxytocin suppresses food intake and causes weight loss in diet-induced obese rats. Am J Physiol Endocrinol Metab 302, E134-144, 2012.

Mountford SJ, Albiston AL, Charman WN, Ng L, Holien JK, Parker MW, Nicolazzo JA, Thompson PE, Chai SY. Synthesis, structure-activity relationships and brain uptake of a novel series of benzopyran inhibitors of insulin-regulated aminopeptidase. J Med Chem 57, 1368-1377, 2014. 
Munoz MC, Giani JF, Burghi V, Mayer MA, Carranza A, Taira CA, Dominici FP. The Mas receptor mediates modulation of insulin signaling by angiotensin-(1-7). Regul Pept 177, 1-11, 2012.

Nagai Y, Ichihara A, Nakano D, Kimura S, Pelisch N, Fujisawa Y, Hitomi H, Hosomi N, Kiyomoto H, Kohno M, Ito $\mathrm{H}$, Nishiyama A. Possible contribution of the non-proteolytic activation of prorenin to the development of insulin resistance in fructose-fed rats. Exp Physiol 94, 1016-1023, 2009.

Netzer N, Gatterer H, Faulhaber M, Burtscher M, Pramsohler S, Pesta D. Hypoxia, Oxidative Stress and Fat. Biomolecules 5, 1143-1150, 2015.

Nguyen G, Delarue F, Burckle C, Bouzhir L, Giller T, Sraer JD. Pivotal role of the renin/prorenin receptor in angiotensin II production and cellular responses to renin. J Clin Invest 109, 1417-1427, 2002.

Nguyen G, Contrepas A. The (pro)renin receptors. J Mol Med (Berl) 86, 643-646, 2008.

Niwa M, Numaguchi Y, Ishii M, Kuwahata T, Kondo M, Shibata R, Miyata K, Oike Y, Murohara T. IRAP deficiency attenuates diet-induced obesity in mice through increased energy expenditure. Biochem Biophys Res Commun 457, 12-18, 2015.

Ogihara T, Asano T, Ando K, Chiba Y, Sakoda H, Anai M, Shojima N, Ono H, Onishi Y, Fujishiro M, Katagiri H, Fukushima Y, Kikuchi M, Noguchi N, Aburatani H, Komuro I, Fujita T. Angiotensin II-induced insulin resistance is associated with enhanced insulin signaling. Hypertension 40, 872-879, 2002.

Olivares-Reyes JA, Arellano-Plancarte A, Castillo-Hernandez JR. Angiotensin II and the development of insulin resistance: implications for diabetes. Mol Cell Endocrinol 302, 128-139, 2009.

Peck GR, Ye S, Pham V, Fernando RN, Macaulay SL, Chai SY, Albiston AL. Interaction of the Akt substrate, AS160, with the glucose transporter 4 vesicle marker protein, insulin-regulated aminopeptidase. Mol Endocrinol 20, 2576-2583, 2006.

Pinterova L, Krizanova O, Zorad S. Rat epididymal fat tissue express all components of the renin-angiotensin system. Gen Physiol Biophys 19, 329-334, 2000.

Plante E, Menaouar A, Danalache BA, Yip D, Broderick TL, Chiasson JL, Jankowski M, Gutkowska J. Oxytocin treatment prevents the cardiomyopathy observed in obese diabetic male $\mathrm{db} / \mathrm{db}$ mice. Endocrinology 156, 1416-1428, 2015.

Qian W, Zhu T, Tang B, Yu S, Hu H, Sun W, Pan R, Wang J, Wang D, Yang L, Mao C, Zhou L, Yuan G. Decreased circulating levels of oxytocin in obesity and newly diagnosed type 2 diabetic patients. J Clin Endocrinol Metab 99, 4683-4689, 2014.

Rogi T, Tsujimoto M, Nakazato H, Mizutani S, Tomoda Y. Human placental leucine aminopeptidase/oxytocinase. A new member of type II membrane-spanning zinc metallopeptidase family. J Biol Chem 271, 56-61, 1996.

Rosen ED, MacDougald OA. Adipocyte differentiation from the inside out. Nat Rev Mol Cell Biol 7, 885-896, 2006.

Ross R, Fortier L, Hudson R. Separate associations between visceral and subcutaneous adipose tissue distribution, insulin and glucose levels in obese women. Diabetes Care 19, 1404-1411, 1996.

Santos RA, Simoes e Silva AC, Maric C, Silva DM, Machado RP, de Buhr I, Heringer-Walther S, Pinheiro SV, Lopes MT, Bader M, Mendes EP, Lemos VS, Campagnole-Santos MJ, Schultheiss HP, Speth R, Walther T. Angiotensin-(1-7) is an endogenous ligand for the G protein-coupled receptor Mas. Proc Natl Acad Sci U S A 100, 8258-8263, 2003.

Santos SH, Fernandes LR, Mario EG, Ferreira AV, Porto LC, Alvarez-Leite JI, Botion LM, Bader M, Alenina N, Santos RA. Mas deficiency in FVB/N mice produces marked changes in lipid and glycemic metabolism. Diabetes 57, 340-347, 2008.

Santos SH, Braga JF, Mario EG, Porto LC, Rodrigues-Machado Mda G, Murari A, Botion LM, Alenina N, Bader M, Santos RA. Improved lipid and glucose metabolism in transgenic rats with increased circulating angiotensin-(1-7). Arterioscler Thromb Vasc Biol 30, 953-961, 2010.

Santos SH, Fernandes LR, Pereira CS, Guimaraes AL, de Paula AM, Campagnole-Santos MJ, Alvarez-Leite JI, Bader $\mathrm{M}$, Santos RA. Increased circulating angiotensin-(1-7) protects white adipose tissue against development of a proinflammatory state stimulated by a high-fat diet. Regul Pept 178, 64-70, 2012.

Santos SH, Andrade JM, Fernandes LR, Sinisterra RD, Sousa FB, Feltenberger JD, Alvarez-Leite JI, Santos RA. Oral Angiotensin-(1-7) prevented obesity and hepatic inflammation by inhibition of resistin/TLR4/MAPK/NFkappaB in rats fed with high-fat diet. Peptides 46, 47-52, 2013.

Santos SH, Giani JF, Burghi V, Miquet JG, Qadri F, Braga JF, Todiras M, Kotnik K, Alenina N, Dominici FP, Santos RA, Bader M. Oral administration of angiotensin-(1-7) ameliorates type 2 diabetes in rats. J Mol Med (Berl) 92, 255-265, 2014.

Sharma AM, Janke J, Gorzelniak K, Engeli S, Luft FC. Angiotensin blockade prevents type 2 diabetes by formation of fat cells. Hypertension 40, 609-611, 2002. 
Schefe JH, Menk M, Reinemund J, Effertz K, Hobbs RM, Pandolfi PP, Ruiz P, Unger T, Funke-Kaiser H. A novel signal transduction cascade involving direct physical interaction of the renin/prorenin receptor with the transcription factor promyelocytic zinc finger protein. Circ Res 99, 1355-1366, 2006.

Schling P, Loffler G. Effects of angiotensin II on adipose conversion and expression of genes of the renin-angiotensin system in human preadipocytes. Horm Metab Res 33, 189-195, 2001.

Sinha MK, Raineri-Maldonado C, Buchanan C, Pories WJ, Carter-Su C, Pilch PF, Caro JF. Adipose tissue glucose transporters in NIDDM. Decreased levels of muscle/fat isoform. Diabetes 40, 472-477, 1991.

Skurk T, van Harmelen V, Hauner H. Angiotensin II stimulates the release of interleukin-6 and interleukin-8 from cultured human adipocytes by activation of NF-kappaB. Arterioscler Thromb Vasc Biol 24, 1199-1203, 2004.

Takayanagi Y, Kasahara Y, Onaka T, Takahashi N, Kawada T, Nishimori K. Oxytocin receptor-deficient mice developed late-onset obesity. Neuroreport 19, 951-955, 2008.

Takeda M, Yamamoto K, Takemura Y, Takeshita H, Hongyo K, Kawai T, Hanasaki-Yamamoto H, Oguro R, Takami Y, Tatara Y, Takeya Y, Sugimoto K, Kamide K, Ohishi M, Rakugi H. Loss of ACE2 exaggerates high-calorie diet-induced insulin resistance by reduction of GLUT4 in mice. Diabetes 62, 223-233, 2013.

Tan P, Shamansurova Z, Bisotto S, Michel C, Gauthier MS, Rabasa-Lhoret R, Nguyen TM, Schiller PW, Gutkowska J, Lavoie JL. Impact of the prorenin/renin receptor on the development of obesity and associated cardiometabolic risk factors. Obesity (Silver Spring) 22, 2201-2209, 2014.

Tan P, Blais C, Nguyen TM, Schiller PW, Gutkowska J, Lavoie JL. Prorenin/renin receptor blockade promotes a healthy fat distribution in obese mice. Obesity (Silver Spring) 24, 1946-1954, 2016.

Tetzner A, Gebolys K, Meinert C, Klein S, Uhlich A, Trebicka J, Villacanas O, Walther T. G-Protein-Coupled Receptor MrgD Is a Receptor for Angiotensin-(1-7) Involving Adenylyl Cyclase, cAMP, and Phosphokinase A. Hypertension 68, 185-194, 2016.

Than A, Leow MK, Chen P. Control of adipogenesis by the autocrine interplays between angiotensin 1-7/Mas receptor and angiotensin II/AT1 receptor signaling pathways. J Biol Chem 288, 15520-15531, 2013.

Thatcher S, Yiannikouris F, Gupte M, Cassis L. The adipose renin-angiotensin system: role in cardiovascular disease. Mol Cell Endocrinol 302, 111-117, 2009.

Tipnis SR, Hooper NM, Hyde R, Karran E, Christie G, Turner AJ. A human homolog of angiotensin-converting enzyme. Cloning and functional expression as a captopril-insensitive carboxypeptidase. J Biol Chem 275, 33238-33243, 2000.

Tojo H, Kaieda I, Hattori H, Katayama N, Yoshimura K, Kakimoto S, Fujisawa Y, Presman E, Brooks CC, Pilch PF. The Formin family protein, formin homolog overexpressed in spleen, interacts with the insulin-responsive aminopeptidase and profilin IIa. Mol Endocrinol 17, 1216-1229, 2003.

Wallis MG, Lankford MF, Keller SR. Vasopressin is a physiological substrate for the insulin-regulated aminopeptidase IRAP. Am J Physiol Endocrinol Metab 293, E1092-1102, 2007.

Wang B, Wood IS, Trayhurn P. Dysregulation of the expression and secretion of inflammation-related adipokines by hypoxia in human adipocytes. Pflugers Arch 455, 479-492, 2007.

Wong YC, Sim MK, Lee KO. Des-aspartate-angiotensin-I and angiotensin IV improve glucose tolerance and insulin signalling in diet-induced hyperglycaemic mice. Biochem Pharmacol 82, 1198-1208, 2011.

Wu CH, Mohammadmoradi S, Thompson J, Su W, Gong M, Nguyen G, Yiannikouris F. Adipocyte (Pro)ReninReceptor Deficiency Induces Lipodystrophy, Liver Steatosis and Increases Blood Pressure in Male Mice. Hypertension 68, 213-219, 2016.

Yamahara N, Nomura S, Suzuki T, Itakura A, Ito M, Okamoto T, Tsujimoto M, Nakazato H, Mizutani S. Placental leucine aminopeptidase/oxytocinase in maternal serum and placenta during normal pregnancy. Life Sci 66, 1401-1410, 2000.

Zhou MS, Schulman IH, Zeng Q. Link between the renin-angiotensin system and insulin resistance: implications for cardiovascular disease. Vasc Med 17, 330-341, 2012.

Zorad S, Dou JT, Benicky J, Hutanu D, Tybitanclova K, Zhou J, Saavedra JM. Long-term angiotensin II AT1 receptor inhibition produces adipose tissue hypotrophy accompanied by increased expression of adiponectin and PPARgamma. Eur J Pharmacol 552, 112-122, 2006. 